\title{
Cluster headache - a study of 387 cases
}

\author{
ME Nobre, ${ }^{*}$ PF Moreira \\ From The European Headache and Migraine Trust International Congress \\ London, UK. 20-23 September 2012
}

\section{Background}

Cluster headache $(\mathrm{CH})$ is a rare disorder with peculiar clinical characteristics. The most recent epidemiological study on suggested that $\mathrm{CH}$ is more common than previously thought and highlighted the long amount of time which elapses from onset of symptoms to diagnosis.

\section{Objectives}

To conduct a nationwide study in order to describe the phenotype of $\mathrm{CH}$ in Brazil. We ultimately aimed to gather clinical data to support and refine the current diagnostic criteria.

\section{Methods}

This study was conducted from January of 2009 to December of 2010. Patients with $\mathrm{CH}$ completed an online questionnaire $(n=658$, and 387 of them were interviewed by phone. We obtained demographic information, initial assigned diagnosis, frequency, schedule, location, lateralization, history of smoking and alcohol consumption.

\section{Results}

$\mathrm{CH}$ was more common in men (73.1\%) than in women at a ratio of 2.7/1. Mean age at the time of assessment was 39.3 years. Most were white (82.7\%). The first medical diagnosis received by these individuals was $\mathrm{CH}$ in only $28.7 \%$ of them. Most had episodic $\mathrm{CH}$ (66.9\%) from the beginning, and $4.4 \%$ had episodic $\mathrm{CH}$ remitted from chronic. $\mathrm{CH}$ strictly on the right side occurred in $48.8 \%$ of the sufferers; strictly on the left occurred in $38.8 \%$. Alternating unilateral $\mathrm{CH}$ for the same attack happened in $2.8 \%$ and for different attacks in $8.3 \%$. Five individuals (1.3\%) had bilateral $\mathrm{CH}$. Tearing was the most frequent associated symptom (84.5\%). Most attacks happened from midnight to $2 \mathrm{am}$. A total of $55.8 \%$ of patients reported smoking, and $56.1 \%$ used alcohol more than twice per week.

\section{Conclusion}

As expected, most sufferers were men, but with a male/ female ratio smaller than previously reported. The proportion of chronic $\mathrm{CH}$ was higher than previously described. Some patients did not have strictly unilateral pain, and this possibility has recently been recognized, although not to the frequency found in our study. Delayed diagnosis was the norm, suggesting that continuous medical education on cluster headaches is necessary in order to relieve the incredible burden of these sufferers.

\section{Published: 21 February 2013}

\section{References}

1. Fischera M, Marziniak M, Gralow I, Evers S: The incidence and prevalence of cluster headache: a meta-analysis of population-based studies. Cephalalgia 2008, 28:614-618.

2. Bahra A, May A, Goadsby PJ: Cluster headache - a prospective clinical study with diagnostic implications. Neurology 2002, 58:354-361.

3. Manzoni GC, Terzano MG, Bono G, Micieli G, Martucci N, Nappi G: Cluster headache - clinical findings in 180 patients. Cephalalgia 1983, 3:21-30.

doi:10.1186/1129-2377-14-S1-P51

Cite this article as: Nobre and Moreira: Cluster headache - a study of 387 cases. The Journal of Headache and Pain 2013 14(Suppl 1):P51.

Submit your manuscript to a SpringerOpen ${ }^{\circ}$ journal and benefit from:

- Convenient online submission

- Rigorous peer review

- Immediate publication on acceptance

- Open access: articles freely available online

- High visibility within the field

- Retaining the copyright to your article

Submit your next manuscript at $>$ springeropen.com 